\title{
Drying kinetics and physiological quality of 'Cabacinha' pepper seeds during storage
}

\author{
Hellismar W. da Silva ${ }^{1}$, Luís S. R. Vale ${ }^{2}$, Camila F. Silva ${ }^{2}$, Rannie do C. Souza ${ }^{2}$ \& Renato S. Soares ${ }^{3}$ \\ ${ }^{1}$ Universidade Federal de Lavras/Departamento de Agricultura. Lavras, MG. E-mail: waksonhellismar@gmail.com - ORCID: 0000-0002-1353-2247 \\ (Corresponding author) \\ ${ }^{2}$ Instituto Federal Goiano/Campus Ceres. Ceres, GO. E-mail: luis.sergio@ifgoiano.edu.br - ORCID: 0000-0002-6303-9063; camilafsagro@gmail.com - \\ ORCID: 0000-0002-2848-1710; ranniesouza@hotmail.com - ORCID: 0000-0002-6462-9209 \\ ${ }^{3}$ Universidade Estadual Paulista/Departamento de Produção Vegetal/Horticultura. Jaboticabal, SP. E-mail: renato_2366@hotmail.com - ORCID: 0000- \\ 0002-9804-1104
}

\section{Key words:}

Capsicum chinense L. drying temperature germination vigor

\begin{abstract}
A B S T R A C T
Drying air temperature has direct influence on seed quality, especially for vegetable species harvested with high moisture content. This study aimed to determine and model the drying curves of 'Cabacinha' pepper seeds (Capsicum chinense L.) at different temperatures, and to evaluate their physiological quality after drying and during storage. The experimental design was completely randomized in a $3 \times 3$ factorial scheme, with three drying temperatures $\left(35,38\right.$ and $\left.42^{\circ} \mathrm{C}\right)$ and three storage periods $(0,4$ and 8 months), with four replicates. Seed quality was evaluated by germination test, first germination count, accelerated aging, electrical conductivity, seedling emergence, and speed of emergence. The Two Terms is the model that best represents the drying curves of 'Cabacinha' pepper seeds at temperatures of 35,38 and $42^{\circ} \mathrm{C}$. Higher germination and vigor values are obtained in seeds dried at 35 and $38^{\circ} \mathrm{C}$. Drying at $42{ }^{\circ} \mathrm{C}$ and storage reduce the physiological quality of the seeds.
\end{abstract}

\section{Palavras-chave: Capsicum chinense L. temperatura de secagem germinação vigor}

\section{Cinética de secagem e qualidade fisiológica de sementes de pimenta Cabacinha durante o armazenamento}

\begin{abstract}
R E S U M O
A temperatura do ar de secagem exerce influência direta sobre a qualidade de sementes, principalmente para espécies olerícolas colhidas com alto teor de água. Objetivou-se, com esta pesquisa, determinar e modelar as curvas de secagem de sementes de pimenta tipo Cabacinha (Capsicum chinense L.) em diferentes temperaturas e avaliar a qualidade fisiológica das sementes após a secagem e durante o armazenamento. Utilizou-se o delineamento experimental inteiramente casualizado em esquema fatorial $3 \times 3$, sendo três temperaturas de secagem $\left(35,38\right.$ e $\left.42^{\circ} \mathrm{C}\right)$ e três períodos de armazenamento $(0,4$ e 8 meses), com quatro repetições. A qualidade das sementes foi avaliada pelo teste de germinação, primeira contagem de germinação, envelhecimento acelerado, condutividade elétrica, emergência de plântulas e velocidade de emergência. $O$ modelo 'Two Terms' é o que melhor representa as curvas de secagem das sementes de pimenta Cabacinha nas temperaturas de 35,38 e $42^{\circ} \mathrm{C}$. Maiores valores de germinação e vigor são obtidos para as sementes secas a 35 e $38^{\circ} \mathrm{C}$. A secagem a $42^{\circ} \mathrm{C}$ e o armazenamento, reduzem a qualidade fisiológica das sementes.
\end{abstract}




\section{INTRODUCTION}

Using seeds of high physiological quality is one of the basic factors for adequate establishment of seedling emergence and successful production of any crop (Silva et al., 2015b), especially for some vegetable species of high added value.

After reaching maximum quality during their development, seeds of fleshy fruit species, such as peppers, commonly show high moisture contents, usually above 40\% (Queiroz et al., 2011; Silva et al., 2015b). The permanence of seeds in this state may induce fermentation and, consequently, reduce their quality (Marcos Filho, 2015). For this reason, seeds must be dried as soon as possible (Nakada et al., 2010).

Studies on drying processes and systems, their dimensioning, optimization and evaluation of commercial-scale application viability can be conducted through mathematical modeling (Resende et al., 2010; Costa et al., 2011). These studies become even more important for seed drying, since the adopted procedures exert direct influence on seed quality and longevity.

Mathematical modeling has been used to represent the drying of various types of seeds, such as crambe (Costa et al., 2011; Faria et al., 2012), urucum (Santos et al., 2013), 'pimenta bode' (Rodovalho et al., 2015), among others. Nonetheless, the current literature has scarce information about drying curves of 'Cabacinha' pepper and about the effect of drying temperature on the physiological quality of its seeds.

Vegetable seeds are usually dried at temperatures from 32 to $42{ }^{\circ} \mathrm{C}$ (Peske et al., 2009). High temperatures may cause irreversible damages to the seeds, especially those harvested with high moisture contents (Queiroz et al., 2011). Low temperatures demand longer time of operation, which in some situations may result in increase of costs and reduction of seed quality, due to the longer time of exposure to high moisture contents (Nakada et al., 2010).

In this context, this study aimed to determine and model the drying kinetics at different temperatures and evaluate the quality of 'Cabacinha' pepper seeds immediately after drying and during storage.

\section{Material AND Methods}

The study was carried out at the Laboratory of Seed Analysis (LAS) of the Federal Institute of Education, Science and Technology of Goiás - Campus Ceres (Instituto Federal de Educação, Ciência e Tecnologia Goiano - Campus Ceres), located in the municipality of Ceres, GO, Brazil. 'Cabacinha' pepper (Capsicum chinense L.) fruits were harvested at full maturity (completely orange) and its seeds were mechanically removed.

After removal, the seeds were subjected to pre-drying by natural convection under laboratory conditions (mean values: $24.6{ }^{\circ} \mathrm{C}$ and $73.1 \%$ of relative air humidity - $\mathrm{RH}$ ) for $24 \mathrm{~h}$, and their moisture content was determined by the oven method at $105 \pm 3{ }^{\circ} \mathrm{C}$ for $24 \mathrm{~h}$ (Brasil, 2009). Then, the seeds were dried in a forced-air oven (TECNAL - Model 394/1) at 35, 38 and $42^{\circ} \mathrm{C}$, under mean RH values of 31.1, 25.5 and $19.6 \%$, respectively. The seeds were dried until reaching adequate moisture content $\left(6 \% \mathrm{~kg}^{-1}\right.$ dry weight) for storage of vegetable seeds in hermetic packages. For each temperature, three replicates of approximately $13 \mathrm{~g}$ of seeds were arranged on metal trays
(26.7, 9.7, and $7.2 \mathrm{~cm})$ in a single layer. Seed moisture content was monitored through gravimetry, by weighing the seeds periodically on analytical scale ( $0.01 \mathrm{~g}$ resolution).

The water removal rate (WRR) of 'Cabacinha' pepper seeds was calculated using Eq. 1 (Resende et al., 2010). WRR was calculated using the initial moisture content $\left(\mathrm{U}_{\mathrm{i}}\right)$, mass of the product $\left(\mathrm{M}_{\mathrm{p}}\right)$ and mass of water $\left(\mathrm{M}_{\mathrm{w}}\right)$ of the product at each drying time.

$$
\mathrm{WRR}=\frac{\mathrm{Mw}_{0}-\mathrm{Mw}_{\mathrm{i}}}{\mathrm{M}_{\mathrm{D}} \cdot\left(\mathrm{t}_{\mathrm{i}}-\mathrm{t}_{0}\right)}
$$

where:

WRR - water removal rate, $\mathrm{kg} \mathrm{kg}^{-1} \mathrm{~h}^{-1}$;

$\mathrm{Mw}_{0}$ - previous total mass of water $\left(\mathrm{M}_{\mathrm{p}}\right.$ at $\left.\mathrm{t}_{0}-\mathrm{M}_{\mathrm{D}}\right)$, kg;

$\mathrm{Mw}_{\mathrm{i}}$ - current total mass of water $\left(\mathrm{M}_{\mathrm{p}}\right.$ at $\left.\mathrm{t}_{\mathrm{i}}-\mathrm{M}_{\mathrm{D}}\right), \mathrm{kg}$;

$M_{D}$ - dry matter $\left[M_{p} x\left(1-U_{i}\right)\right]$, kg;

$\mathrm{t}_{0} \quad$ - previous total drying time, $\mathrm{h}$; and,

$t_{i} \quad$ - current total drying time, $h$.

Moisture ratios (MR) were calculated during the drying at different temperatures, using the following expression (Silva et al., 2016):

$$
\mathrm{MR}=\frac{\mathrm{M}-\mathrm{M}_{\mathrm{e}}}{\mathrm{M}_{\mathrm{i}}-\mathrm{M}_{\mathrm{e}}}
$$

where:

M - moisture content of the product at each drying time, decimal (d.b.);

$\mathrm{M}_{\mathrm{i}} \quad$ - initial moisture content of the product, decimal (d.b.); and,

$\mathrm{M}_{\mathrm{e}}$ - equilibrium moisture content of the product, decimal (d.b.).

The equilibrium moisture content of the seeds under each drying condition was calculated using the model of Cavalcante Mata, whose values were 4.82, 4.09 and 3.31\% (d.b.), respectively, for temperatures of 35,38 and $42{ }^{\circ} \mathrm{C}$ and relative air humidity of $31.1,25.5$ and $19.6 \%$. This model was recommended by Silva et al. (2015a) to estimate the desorption isotherms of 'Cabacinha' pepper (Capsicum chinense L.) seeds.

Ten mathematical models frequently used to represent the drying of seeds of different species were fitted to the moisture ratio experimental data (Faria et al., 2012; Siqueira et al., 2012; Santos et al., 2013), as described in Table 1.

Table 1. Mathematical models used to predict the drying

\begin{tabular}{|c|c|c|}
\hline Model designation & Model & \\
\hline Approximation of Diffusion & $R M=a \exp (-k t)+(1-a) \exp (-k b t)$ & (3) \\
\hline Two terms & $R M=a \exp (-k t)+b \exp (-c t)$ & (4) \\
\hline Exp. Two Terms & $R M=a \exp (-k t)+(1-a) \exp (-k a t)$ & (5) \\
\hline Henderson-Pabis & $R M=a \exp (-k t)$ & (6) \\
\hline Midilli & $R M=a \exp \left(-k t^{b}\right)+c t$ & (7) \\
\hline Modified Midilli & $R M=\exp \left(-k t^{n}\right)+a t$ & (8) \\
\hline Page & $R M=\exp \left(-k t^{n}\right)$ & $(9)$ \\
\hline Modified Page & $R M=\exp \left(-k t^{n}\right)$ & (10) \\
\hline Thompson & $R M=\exp \left(-(k t)^{n}\right)$ & (11) \\
\hline Verna & $R M=a \exp (-k t)+(1-a) \exp (-b t)$ & (12) \\
\hline
\end{tabular}
phenomenon 
The mathematical models were fitted through linear regression, by the Gauss-Newton method. The degree of fit of each model was evaluated based on the magnitude of the coefficient of determination $\left(\mathrm{R}^{2}\right)$, relative mean error $(\mathrm{P})$, estimated mean error (SE) and residual distribution pattern (Camicia et al., 2015; Silva et al., 2016). P and SE were calculated using the following expressions:

$$
\begin{gathered}
P=\frac{100}{n} \sum_{i=1}^{n}\left(\frac{|Y-\hat{Y}|}{Y}\right) \\
S E=\sqrt{\frac{\sum_{i=1}^{n}(Y-\hat{Y})^{2}}{D F}}
\end{gathered}
$$

where:

$$
\begin{array}{ll}
Y & \text { - experimental value, dimensionless; } \\
\hat{Y} & \text { - value estimated by the model, dimensionless; } \\
n & \text { - number of experimental observations; and, } \\
D F & \text { - degrees of freedom of the model. }
\end{array}
$$

After drying at each temperature, the seeds were placed in aluminum paper bag (hermetic package), widely used to store seeds of vegetable species, and stored in refrigerator $\left(4^{\circ} \mathrm{C}\right.$ and $72 \% \mathrm{RH})$ for 0,4 and 8 months. In each period of storage, seed quality was evaluated by the germination test, first germination count (Brasil, 2009), accelerated aging (Torres, 2005), electrical conductivity (Vieira \& Krzyzanowski, 1999), emergence (Silva et al., 2015b) and seedling emergence speed (Maguire, 1962). All tests were carried out using four replicates of 50 seeds for each treatment.

A completely randomized design was used, in $3 \times 3$ factorial scheme with split plots in time, corresponding to three drying temperatures $\left(35,38\right.$ and $\left.42^{\circ} \mathrm{C}\right)$ and three storage periods $(0,4$ and 8 months). The data were subjected to analysis of variance and means were compared by Scott-Knott test $(\mathrm{p}<0.05)$.

\section{Results AND Discussion}

The moisture content of 'Cabacinha' pepper seeds after predrying was approximately $14 \%$ d.b. (Figure 1A). The drying

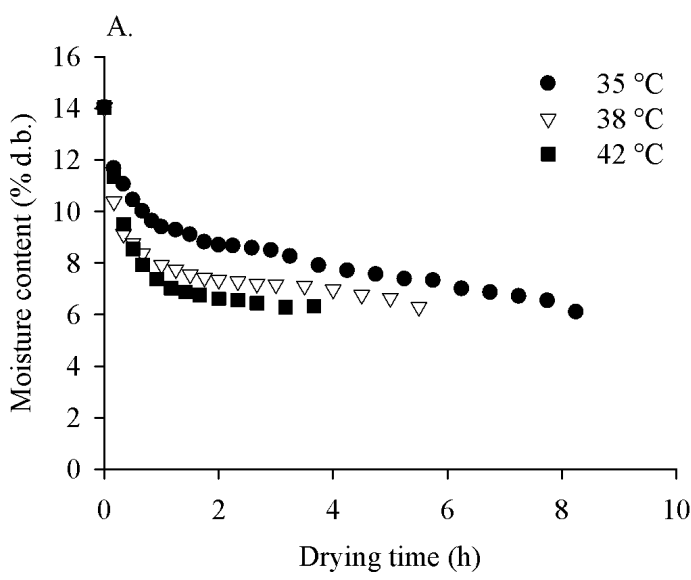

Figure 1. Moisture content (A) and water removal rate (B) during the drying of 'Cabacinha' pepper seeds at different temperatures

times required to reduce seed moisture content to $6 \%$ were 8.2, 5.5 and $3.7 \mathrm{~h}$, respectively, for the temperatures of 35,38 and $42{ }^{\circ} \mathrm{C}$. The reduction in drying time can be explained by the higher water removal rate observed at higher temperatures (Figure 1B).

Highest water removal rates occurred in the first hour of drying (Figure $1 \mathrm{~B}$ ), and the mean values for this period were $0.046,0.071$ and $0.078 \mathrm{~kg} \mathrm{~kg}^{-1} \mathrm{~h}^{-1}$, at temperatures of 35,38 and $42{ }^{\circ} \mathrm{C}$, respectively. Regardless of temperature, highest water removal rates occurred in the first hour of drying. After this period, the values gradually decreased and remained constant, possibly because the water was strongly bound to the sorption sites of the seeds (Resende et al., 2010). Similar results were observed for seeds of urucum (Santos et al., 2013) and 'pimenta bode' (Rodovalho et al., 2015).

Among the models fitted to the drying data of 'Cabacinha' pepper seeds (Table 2), Approximation of diffusion, Two terms, Midilli, Modified Midilli, Page and Modified Page showed coefficients of determination $\left(\mathrm{R}^{2}\right)$ higher than 0.980 for the temperatures of 35,38 and $42{ }^{\circ} \mathrm{C}$. The other models, except Thompson at temperatures of 35 and $42^{\circ} \mathrm{C}$, showed coefficients of determination below 0.929 for all temperatures studied.

Most models fitted showed high coefficients of determination. Hence, using only this parameter is not sufficient to select nonlinear models (Camicia et al., 2015). For this reason, the relative mean error $(\mathrm{P})$, estimated mean error (SE) and residual distribution were analysed.

For a model to satisfactorily represent any phenomenon, it must show relative mean error lower than $10 \%$, estimated mean error as closest to zero as possible and random residual distribution. The models Approximation of Diffusion and Two Terms showed the best statistical results $(\mathrm{P}<1.036 \%$ and $\mathrm{SE}<0.035)$ and exhibited random residual distribution for the three temperatures studied (Table 2), which according to Silva et al. (2016) characterizes their adequacy to represent the phenomenon studied.

For having simpler mathematical operations than the Approximation of Diffusion, the Two Terms model was used to represent the drying curves of 'Cabacinha' pepper seeds at temperatures of 35,38 and $42{ }^{\circ} \mathrm{C}$, and its regression coefficients are presented in Eq. 15, 16 and 17, respectively for each temperature.

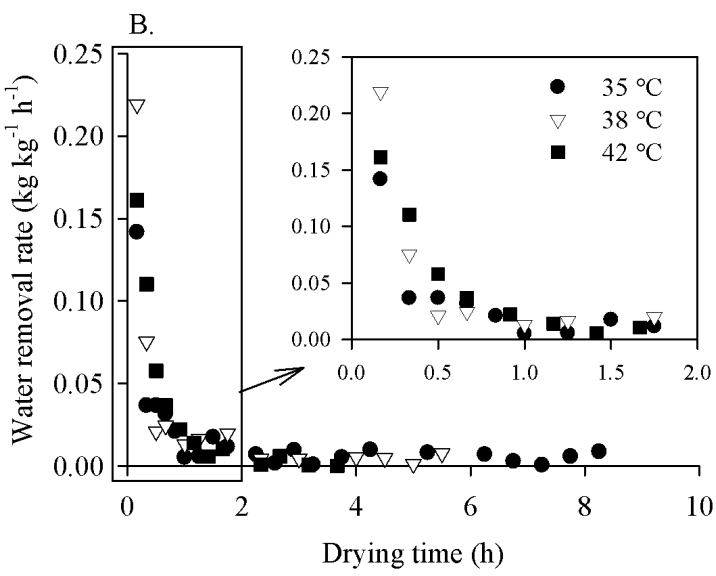

R. Bras. Eng. Agríc. Ambiental, v.22, n.4, p.292-297, 2018. 
Table 2. Coefficients of determination $\left(R^{2}\right)$, relative mean error $(P, \%)$, estimated mean error (SE, decimal) and residual distribution (RD) for the models fitted to the experimental data of drying of 'Cabacinha' pepper seeds

\begin{tabular}{|c|c|c|c|c|c|c|c|c|c|c|c|c|}
\hline \multirow{2}{*}{ Models } & $\mathbf{R}^{2}$ & $\mathbf{P}$ & SE & RD & $\mathbf{R}^{2}$ & $\mathbf{P}$ & SE & RD & $\mathrm{R}^{2}$ & $\mathbf{P}$ & SE & RD \\
\hline & \multicolumn{4}{|c|}{$35^{\circ} \mathrm{C}$} & \multicolumn{4}{|c|}{$38^{\circ} \mathrm{C}$} & \multicolumn{4}{|c|}{$42^{\circ} \mathrm{C}$} \\
\hline Approximation of Diffusion & 0.997 & 0.699 & 0.034 & RN & 0.997 & 1.020 & 0.032 & RN & 0.999 & 0.276 & 0.009 & RN \\
\hline Two Terms & 0.997 & 1.036 & 0.035 & RN & 0.997 & 1.022 & 0.027 & RN & 0.999 & 0.277 & 0.007 & $\mathrm{RN}$ \\
\hline Exp. Two Terms & 0.825 & 8.885 & 0.383 & BS & 0.517 & 12.343 & 0.452 & BS & 0.830 & 9.049 & 0.300 & BS \\
\hline Henderson-Pabis & 0.926 & 3.775 & 0.257 & BS & 0.784 & 6.548 & 0.328 & BS & 0.851 & 7.457 & 0.282 & BS \\
\hline Midilli & 0.996 & 1.274 & 0.042 & RN & 0.996 & 1.252 & 0.035 & RN & 0.996 & 1.358 & 0.034 & RN \\
\hline Modified Midilli & 0.996 & 1.270 & 0.049 & $\mathrm{RN}$ & 0.996 & 1.249 & 0.040 & RN & 0.996 & 1.351 & 0.040 & RN \\
\hline Page & 0.994 & 1.956 & 0.076 & $\mathrm{RN}$ & 0.994 & 1.400 & 0.057 & $\mathrm{RN}$ & 0.980 & 2.710 & 0.106 & BS \\
\hline Modified Page & 0.994 & 1.956 & 0.076 & $\mathrm{RN}$ & 0.994 & 1.400 & 0.057 & $\mathrm{RN}$ & 0.980 & 2.710 & 0.106 & BS \\
\hline Thompson & 0.989 & 2.252 & 0.101 & $\mathrm{RN}$ & 0.929 & 5.298 & 0.196 & BS & 0.972 & 3.863 & 0.126 & BS \\
\hline Verna & 0.926 & 3.775 & 0.209 & BS & 0.784 & 6.549 & 0.268 & BS & 0.851 & 7.458 & 0.231 & BS \\
\hline
\end{tabular}

RN - Random distribution; BS - Biased distribution

$$
\begin{aligned}
\mathrm{MR}_{35{ }^{\circ} \mathrm{C}} & =0.4111^{* *} \exp \left(-4.0716^{* *} \mathrm{t}\right)+ \\
& +0.5801^{* *} \exp \left(-0.1447^{* *} \mathrm{t}\right) \\
\mathrm{MR}_{38{ }^{\circ} \mathrm{C}} & =0.5692^{* *} \exp \left(-5.3325^{* *} \mathrm{t}\right)+ \\
& +0.4254^{* *} \exp \left(-0.1084^{* *} \mathrm{t}\right) \\
\mathrm{MR}_{42{ }^{\circ} \mathrm{C}} & =0.6445^{* *} \exp \left(-2.9917^{* *} \mathrm{t}\right)+ \\
& +0.3565^{* *} \exp \left(-0.0718^{* *} \mathrm{t}\right)
\end{aligned}
$$

where:

$$
\text { - significant at } 0.01 \text { by t-test. }
$$

The drying curves of 'Cabacinha' pepper seeds at temperatures of 35,38 and $42{ }^{\circ} \mathrm{C}$, and the values estimated by the Two Terms model are presented in Figure 2.

The Two Terms model also showed satisfactory fit to the drying curves of coffee beans (Resende et al., 2010), jatropha seeds (Siqueira et al., 2012) and urucum seeds (Santos et al., 2013).

For seed physiological quality, only germination speed showed significant interaction for drying temperature and storage time. Regardless of the test used, there was no

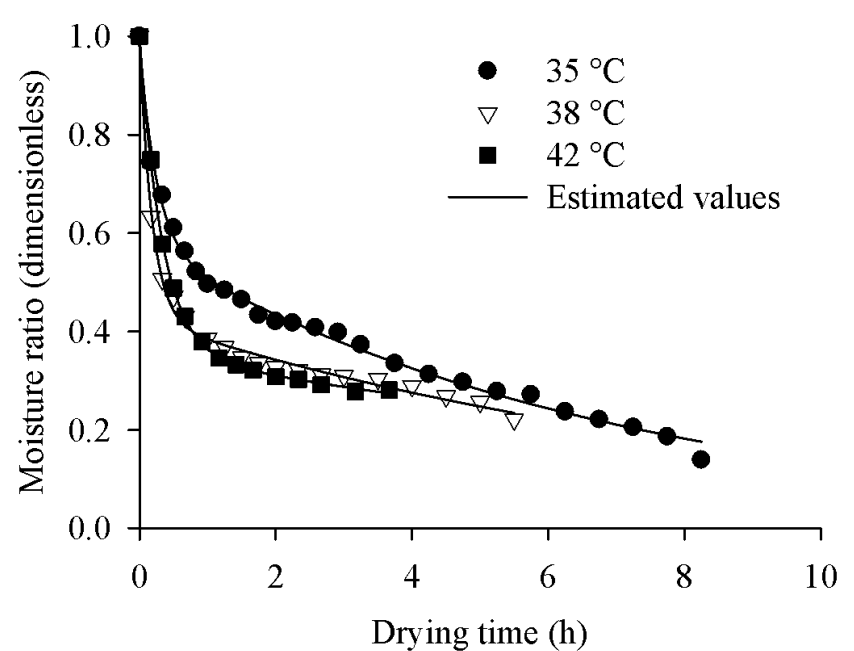

Figure 2. Experimental values and values estimated by the Two Terms model for moisture ratio as a function of drying time of 'Cabacinha' pepper seeds difference in the quality of the seeds subjected to drying at 35 and $38^{\circ} \mathrm{C}$ (Table 3 ). Drying at $42{ }^{\circ} \mathrm{C}$ significantly reduced first germination count, germination and seedling emergence, but it did not influence germination after accelerated aging and electrical conductivity.

Slow drying of seeds, performed under field conditions (still in the mother plant) or at low temperature in a dryer, allows gradual reduction in the moisture content and, consequently, the action of mechanisms of tolerance to water removal (Marcos Filho, 2015). Hence, the higher water removal rate observed for the drying at $42^{\circ} \mathrm{C}$ (Figure $1 \mathrm{~B}$ ) may possibly have caused damages to the seeds, reducing their quality.

In studies with Habanero pepper, Queiroz et al. (2011) observed that the quality of seeds dried at $35{ }^{\circ} \mathrm{C}$ was significantly superior compared with those dried at $45^{\circ} \mathrm{C}$, and attributed such behavior to oxidative processes and production of free radicals induced by the fast drying at the highest temperature. Working with Habanero pepper, Santos et al. (2016) also obtained seeds with better quality for the drying at $35^{\circ} \mathrm{C}$, in comparison to natural drying.

Pepper seed germination increased during the eight months of storage (Table 3). First germination count and seedling emergence also increased after four months, but there was reduction after eight months of storage. Increment in pepper seed germination during storage is an indication of breaking of secondary dormancy (Caixeta et al., 2014; Lima \& Smiderle, 2014).

The accelerated aging test was proposed to evaluate seed storage potential (Marcos Filho, 2015). On the other hand,

Table 3. Mean values for first germination count (FGC), germination $(G)$, seedling emergence $(S E)$, germination after accelerated aging (AA) and electrical conductivity (EC) of 'Cabacinha' pepper seeds subjected to different drying temperatures (DT) and storage times (ST)

\begin{tabular}{cccccc} 
& FGC & G & SE & AA & \begin{tabular}{c} 
EC \\
\cline { 2 - 5 }$\left(\boldsymbol{\mu} \mathbf{c m}^{-1} \mathbf{~ g}^{-1}\right)$
\end{tabular} \\
DT $\left({ }^{\circ} \mathrm{C}\right)$ & \multicolumn{3}{c}{$(\%)$} \\
35 & $52 \mathrm{a}$ & $74 \mathrm{a}$ & $89 \mathrm{a}$ & $62 \mathrm{a}$ & $91.22 \mathrm{a}$ \\
38 & $58 \mathrm{a}$ & $78 \mathrm{a}$ & $88 \mathrm{a}$ & $69 \mathrm{a}$ & $108.22 \mathrm{a}$ \\
42 & $40 \mathrm{~b}$ & $65 \mathrm{~b}$ & $81 \mathrm{~b}$ & $57 \mathrm{a}$ & $91.48 \mathrm{a}$ \\
\hline ST (months) & & & & & \\
0 & $54 \mathrm{~b}$ & $61 \mathrm{~b}$ & $85 \mathrm{~b}$ & $76 \mathrm{a}$ & $79.75 \mathrm{~b}$ \\
4 & $69 \mathrm{a}$ & $76 \mathrm{a}$ & $94 \mathrm{a}$ & $69 \mathrm{~b}$ & $101.35 \mathrm{a}$ \\
8 & $26 \mathrm{c}$ & $80 \mathrm{a}$ & $79 \mathrm{c}$ & $43 \mathrm{C}$ & $109.82 \mathrm{a}$ \\
\hline
\end{tabular}

Means followed by the same letter in the column do not differ by Scott-Knott test $(p<0.05)$ 
the electrical conductivity, measured based on the quantity of salts released during soaking, evaluates the integrity of cell membranes (Vieira \& Krzyzanowski, 1999). Therefore, reduction in germination after accelerated aging and increase in electrical conductivity characterize some physiological and biochemical signs that may be related to deterioration of pepper seeds during storage (Table 3 ).

The immediate effect of drying temperature on emergence speed was observed only in the beginning of storage, with lower value for seeds subjected to drying at $42^{\circ} \mathrm{C}$ (Table 4 ). For those subjected to drying at $35^{\circ} \mathrm{C}$, emergence speed remained constant until four months and decreased after eight months of storage. At the other temperatures, this variable increased after four months and decreased after eight months of storage.

The reduction in emergence speed at eight months of storage (Table 4) coincides with the decrease in first germination count, accelerated aging and seedling emergence, as well as with the increase in electrical conductivity (Table 3 ).

According to Marcos Filho (2015), reduction in emergence speed is also an indication of seed deterioration, and the damages are related to the integrity of the cell membrane. In studies with yellow 'dedo-de-moça' pepper seeds, the emergence speed index was inversely proportional to electrical conductivity (Silva et al., 2015b).

Table 4. Mean values for emergence speed of 'Cabacinha' pepper seeds subjected to different drying temperatures and storage times

\begin{tabular}{ccccc|}
\hline Drying temperature & \multicolumn{4}{c}{ Storage time (months) } \\
\cline { 2 - 5 }$\left({ }^{\circ} \mathrm{C}\right)$ & $\mathbf{0}$ & $\mathbf{4}$ & $\mathbf{8}$ \\
35 & $1.563 \mathrm{aA}$ & $1.558 \mathrm{a} \mathrm{A}$ & $1.218 \mathrm{aB}$ \\
38 & $1.489 \mathrm{aB}$ & $1.684 \mathrm{a} \mathrm{A}$ & $1.105 \mathrm{aC}$ \\
42 & $1.202 \mathrm{bB}$ & $1.552 \mathrm{a} \mathrm{A}$ & $1.029 \mathrm{aB}$ \\
\hline
\end{tabular}

Means followed by the same letter, lowercase in the column and uppercase in the row, do not differ by Scott-Knott test $(p<0.05)$

\section{Conclusions}

1. Two Terms is the model that best represents the drying curves of 'Cabacinha' pepper seeds at temperatures of 35, 38 and $42{ }^{\circ} \mathrm{C}$.

2. Higher values of germination and vigor are obtained for seeds dried at 35 and $38^{\circ} \mathrm{C}$.

3. Drying at $42^{\circ} \mathrm{C}$ and storage reduce seed quality.

\section{Literature Cited}

Brasil. Ministério da Agricultura e Reforma Agrária. Regras para análise de sementes / Ministério da Agricultura Pecuária e Abastecimento. Secretaria Nacional de Defesa Agropecuária. Brasília: MAPA/ACS, 2009. 399p.

Caixeta, F.; Pinho, E. V. de R. von; Guimarães, R. M.; Pereira, P. H. A. R.; Catão, H. C. R. M. Physiological and biochemical alterations during germination and storage of habanero pepper seeds. African Journal of Agricultural Research, v.9, p.627-635, 2014. https://doi. org/10.5897/AJAR2013.7133

Camicia, R. G. da M.; Christ, D.; Coelho, S. R. M.; Camicia, R. F. da M. Modelagem do processo de secagem de sementes de feijão-caupi. Revista Caatinga, v.28, p.206-214, 2015. https://doi. org/10.1590/1983-21252015v28n323rc
Costa, L. M.; Resende, O.; Sousa, K. A.; Gonçalves, D. N. Coeficiente de difusão efetivo e modelagem matemática da secagem de sementes de crambe. Revista Brasileira de Engenharia Agrícola e Ambiental, v.15, p.1089-1096, 2011. https://doi.org/10.1590/ S1415-43662011001000014

Faria, R. Q. de; Teixeira, I. R.; Devilla, I. A.; Ascheri, D. P. R.; Resende, O. Cinética de secagem de sementes de crambe. Revista Brasileira de Engenharia Agrícola e Ambiental, v.16, p.573-583, 2012. https://doi.org/10.1590/S1415-43662012000500014

Lima, J. M. E.; Smiderle, O. J. Qualidade fsiológica de sementes de pimenta obtidas em frutos de diferentes maturações e armazenadas. Revista Semina: Ciências Agrárias, v.35, p.251-258, 2014. https://doi.org/10.5433/1679-0359.2014v35n1p251

Maguire, J. D. Speed of germination: Aid in selection and evaluation for seedling emergence and vigour. Crop Science, v.2, p.176-177, 1962. https://doi.org/10.2135/cropsci1962.0011183X000200020033x

Marcos Filho, J. Fisiologia de sementes de plantas cultivadas. 2.ed. Londrina: ABRATES, 2015. 660p.

Nakada, P. G.; Oliveira, J. A.; Melo, L. C. de; Silva, A. S. da; Silva, P. A. da; Perina, F. J. Desempenho durante o armazenamento de sementes de pepino submetidas a diferentes métodos de secagem. Revista Brasileira de Sementes, v.32, p.042-051, 2010. http:// dx.doi.org/10.1590/S0101-31222010000300005

Peske, S. T.; Villela, F. A.; Labbé-Baudet, L. Secagem de hortaliças. In: Nascimento, W. M. Tecnologia de sementes de hortaliças. Brasília: Embrapa, 2009. p.137-151.

Queiroz, L. A. F.; Pinho, E. V. de R. von; Oliveira, J. A.; Ferreira, V. de F.; Carvalho, B. O.; Bueno, A. C. R. Época de colheita e secagem na qualidade de sementes de pimenta Habanero Yellow. Revista Brasileira de Sementes, v.33, p. 472-481, 2011. https://doi. org/10.1590/S0101-31222011000300010

Resende, O.; Rodrigues, S.; Siqueira, V. C.; Arcanjo, R. V. Cinética da secagem de clones de café (Cofea canephora Pierre) em terreiro de chão batido. Acta Amazonica, v.40, p.247-256, 2010. https:// doi.org/10.1590/S0044-59672010000200002

Rodovalho, R. S.; Silva, H. W. da; Silva, I. L.; Rossetto, C. A. V. Cinética de secagem dos grãos de pimenta bode. Global Science and Technology, v.8, p.128-142, 2015. https://doi.org/10.14688/19843801/gst.v8n2p128-142

Santos, D. da C.; Queiroz, A. J. de M.; Figueirêdo, R. M. F. de; Oliveira, E. N. A. de. Mathematical modeling for the annatto (Bixa orellana $\mathrm{L}$.) seed drying process. Chilean Journal Of Agricultural Research, v.73, p.320-326, 2013. https://doi.org/10.4067/S0718-58392013000300017

Santos, H. O. dos; Dutra, S. M. F.; Pereira, R. W.; Pires, R. M. de O.; Pinho, E. V. de R. von; Rosa, S. D. V. F. da; Carvalho, M. L. M. de. Physiological quality of habanero pepper (Capisicum chinense) seeds based on development and drying process. African Journal of Agricultural Research, v.11, p.1102-1109, 2016. https://doi. org/10.5897/AJAR2015.10462

Silva, H. W. da; Costa, L. M.; Resende, O.; Oliveira, D. E. C. de; Soares, R. S.; Vale, L. S. R. Higroscopicidade das sementes de pimenta (Capsicum chinense L.). Revista Brasileira de Engenharia Agrícola e Ambiental, v.19, p.780-784, 2015a. https://doi.org/10.1590/18071929/agriambi.v19n8p780-784

Silva, H. W. da; Soares, R. S.; Vale, L. S. R. Qualidade das sementes de pimenta dedo-de-moça em função do repouso pós-colheita dos frutos. Revista de Ciência Agrárias, v.58, p.427-433, $2015 \mathrm{~b}$. https://doi.org/10.4322/rca.2129 
Silva, H. W. da; Rodovalho, R. S.; Velasco, M. F.; Silva, C. F.; Vale, L. S. R. Kinetics and thermodynamic properties related to the drying of 'Cabacinha' pepper fruits. Revista Brasileira de Engenharia Agrícola e Ambiental, v.20, p.174-180, 2016. https:// doi.org/10.1590/1807-1929/agriambi.v20n2p174-180

Siqueira, V. C.; Resende, O.; Chaves, T. H. Drying kinetics of jatropha seeds. Revista Ceres, v.59, p.171-177, 2012. https://doi. org/10.1590/S0034-737X2012000200004
Torres, S. B. Envelhecimento acelerado em sementes de pimentamalagueta (Capsicum frutescens L.). Revista Ciência Agronômica, v.36, p.98-104, 2005.

Vieira, R. D.; Krzyzanowski, F. C. Teste de condutividade elétrica. In: Krzyzanowski, F. C.; Vieira, R. D.; França Neto, J. de B. Vigor de sementes: Conceitos e testes. Londrina: ABRATES, 1999. p.4.1-4.26. 